Jurnal Health Reproductive

Avalilable Online http://e-journal.sari-mutiara.ac.id/index.php/JRH

\title{
ANALISIS KETERKAITAN PERILAKU ORANGTUA TENTANG SERIBU HARI PERTAMA KEHIDUPAN DENGAN KEJADIAN STUNTING DI WILAYAH KERJA PUSKESMAS DESA LAMA
}

\author{
Agnes Purba \\ Program Studi Kebidanan Program Sarjana Universitas Sari Mutiara Indonesia \\ Korespondensi : agnespurba24@yahoo.co.id
}

\begin{abstract}
ABSTRAK
Kejadian stuntingmasih terdapat di Wilayah Kerja Puskesmas Desa Lama. Stunting ini berkaitan dengan perilaku orangtua tentang seribu hari pertama kehidupan.Penelitian ini bertujuan untuk mengetahui analisis keterkaitan perilaku orangtua tentang seribu hari pertama kehidupan dengan kejadian stunting di Wilayah Kerja Puskesmas Desa Lama.Jenis penelitian yang digunakan adalah penelitian survei analitik dengan desain cross sectional. Populasi dalam penelitian ini adalah seluruh ibu yang memiliki anak usia 2 tahun di Wilayah Kerja Puskesmas Desa Lama yang berjumlah 143 orang dan sampel berjumlah 59 orang. Pengumpulan data dengan data primer dan sekunder dan dianalisis dengan uji statistikchi Squaredengan tingkat kepercayaan 95\%.Hasil penelitianmenunjukkan bahwa perilaku orangtua tentang seribu hari pertama kehidupan di wilayah kerja Puskesmas Desa Lamamayoritas denganperilaku tidak baiksebesar 50,8\%, kejadian stunting di wilayah kerja Puskesmas Desa Lama sebesar 40,7\% dan terdapatketerkaitanperilaku orangtua tentang seribu hari pertama kehidupan dengan kejadian stunting di wilayah kerja Puskesmas Desa Lama. Disarankan kepada ibu di wilayah kerja Puskesmas Desa Lama perlu meningkatkan penerapan perilaku orangtua tentang seribu hari pertama kehidupan dan kepada tenaga kesehatan di wilayah kerja Puskesmas Desa Lama perlu meningkatkan pemahaman ibu tentang pentingnya penerapan perilaku orangtua tentang seribu hari pertama kehidupan untuk mencegah kejadian stunting.
\end{abstract}

\section{Kata Kunci : Perilaku, Kejadian Stunting}

\section{ABSTRACT}

The incidence of stunting in the Working Area of the Old Village Health Center is related to the behavior of parents about the first thousand days of life. This study aims to determine the correlation analysis of parental behavior about the first thousand days of life with the incidence of stunting in the work area of the Old Village Health Center. This type of research is analytic survey research with cross sectional design. The population in this study were all mothers who had children aged 2 years in the working area of the Puskesmas Desa Lama, totaling 143 people and a sample of 59 people. Data collection with primary and secondary data and analyzed by chi Square statistical test with a confidence level of 95\%. The results showed that the majority of parents 'behavior about the first thousand days of life in the work area of the Desa Lama Community Health Center was 50.8\% with bad behavior, the incidence of stunting in the Puskesmas Desa Lama work area was $40.7 \%$ and there was a correlation between parents' behavior about the first thousand days. life with the incidence of stunting in the work area of the Old Village Health Center. It is suggested that mothers in the work area of the Old Village Community Health Center need to improve the application of parental behavior regarding the first thousand days of life and to health workers in the work area of the Old Village Community Health Center it is necessary to increase the mother's understanding of the importance of implementing parental behavior about the first thousand days of life to prevent stunting.

Keywords: Behavior, Stunting Incidence

Universitas Sari Mutiara Indonesia

DOI 


\section{PENDAHULUAN}

Stunting merupakan gangguan pertumbuhan fisik yang ditandai dengan penurunan kecepatan pertumbuhan dan merupakan dampak dari ketidak seimbangan gizi (NHF Losong \& $\mathrm{M}$ Adriani, 2017). Hal ini menimbulkan gangguan perkembangan fisik anak yang irreversible, sehingga menyebabkan penurunan kemampuan kognitif dan motorik serta penurunan performa kerja. Anak stunting memiliki rerata skor Intelligence Quotient (IQ) sebelas poin lebih rendah dibandingkan rerata skor IQ pada anak normal. Gangguan tumbuh kembang pada anak akibat kekurangan gizi bila tidak mendapatkan intervensi sejak dini akan berlanjut hingga dewasa (Kemenkes RI, 2016).

Untuk mengatasi permasalahan gizi ini, di Indonesia dilakukan Gerakan scaling up nutrition atau dikenal dengan Gerakan Nasional Percepatan Perbaikan Gizi dalam rangka Seribu Hari Pertama Kehidupan (Gerakan 1000 HPK) dengan landasan berupa Peraturan Presiden (Perpres) nomor 42 tahun 2013 tentang Gerakan Nasional Percepatan Perbaikan Gizi(Agus Samsudrajat S \& Jati, 2018).Seribu hari pertama kehidupan telah disepakati oleh para ahli di seluruh dunia sebagai saat yang terpenting dalam hidup seseorang. Sejak saat perkembangan janin di dalam kandungan, hingga ulang tahun yang kedua menentukan kesehatan dan kecerdasan seseorang. Makanan selama kehamilan dapat mempengaruhi fungsi memori, konsentrasi, pengambilan keputusan, intelektual, dan emosi seorang anak di kemudian hari (L Mubasyiroh \& Z C Aya, 2018).

Hasil Penelitian Sunarsih et.,al (2017) mengenai gambaran pengetahuan ibu hamil tentang program 1000 HPK di Puskesmas Melati II Yogyakarta menunjukkan pengetahuan ibu tentang program 1000 HPK termasuk kategori kurang (50\%). Hasil Penelitian Ni'mah (2015) mengenai faktor yang berhubungan dengan stunting menunjukkan terdapat hubungan antara panjang badan lahir balita, riwayat ASI eksklusif, pendapatan keluarga, pendidikan ibu dan pengetahuan gizi ibu terhadap kejadian stunting pada balita (Sunarsih et al., 2020).

Hasil studi pendahuluan yang telah dilakukan di wilayah kerja Puskesmas Desa Lama diperoleh bahwa dari 10 orang anak umur 1 tahun diukur tinggi badannya terdapat 3 orang anak tinggi dibawah $75 \mathrm{~cm}$ dan 7 orang dengan tinggi badan yang diatas $75 \mathrm{~cm}$ dan berat badan dibawah 7,7 $\mathrm{kg}$ sebanyak 4 orang dan berat badan diatas $7,7 \mathrm{~kg}$ sebanyak 6 orang. Kemudian dari 10 orang anak dengan umur 2 tahun terdapat 6 orang anak tinggi badan diatas $87 \mathrm{~cm}$ dan 4 orang dengan tinggi badan yang dibawah $87 \mathrm{~cm}$ dan berat badan dibawah 9,7 kg sebanyak 4 orang dan berat badan diatas 9,7 kg sebanyak 6 orang. Keadaan ini menunjukkan bahwa balita masih terdapat mengalami stunting.

Fenomena yang terjadi di wilayah kerja Puskesmas Desa Lama menunjukkan masih terdapat perilaku selama 1000 HPK yang meningkatkan kerentanan terjadinya stunting. Misalnya, masih banyak ibu hamil yang tidak paham mengenai stunting dan tidak meyakini bahwa stunting bisa terjadi akibat pola makan yang salah, sehingga ia tidak melakukan pencegahan sejak awal. Sebagian ibu merasa bahwa kehamilan adalah kondisi biasa saja, jadi tidak memperbaiki pola makannya. Sebagian lain menganggap bahwa makan saat hamil diperuntukkan bagi dua orang. Akibatnya, hanya porsi nasi yang ditambah, agar kenyang. Belum lagi mitos untuk menghindari daging merah, makanan laut dan kacang-kacangan, yang akhirnya membuat ibu hamil kekurangan protein. Saat melahirkan, masih banyak ibu yang tidak melakukan IMD (inisiasi menyusui dini).Berdasarkan uraian di atas, penulis tertarik untuk meneliti tentang analisis keterkaitan perilaku orangtua tentang seribu hari pertama kehidupan dengan kejadian stunting di Wilayah Kerja Puskesmas Desa Lama.

\section{Universitas Sari Mutiara Indonesia}




\section{METODE}

Jenis penelitian yang digunakan pada penelitian ini adalah analitik dengan desain cross sectional dimana variabel perilaku orangtua dan variabel kejadian stunting diteliti secara bersamaan dan dalam satu waktu, bertujuan untuk mengetahui ada tidaknya hubungan antara perilaku orang tua tentang seribu hari pertama kehidupan dengan kejadian stunting. Populasi dalam penelitian ini adalah seluruh ibu yang memiliki anak usia 2 tahun di Wilayah Kerja Puskesmas Desa Lama yang berjumlah 143 orang. Teknik pengambilan sampel dalam penelitian ini adalah simple random sampling dengan kriteria inklusi responden adalah yaitu ibu yang memiliki anak berusia 2 tahundan bersedia menjadi responden. Sedangkan kriteria eksklusi yaitu responden dengan lama tinggal diwilayah Kerja Puskesmas Desa Lama belum 1 tahun, sehingga besar sampel sebanyak 59 orang.

Pengumpulan data pada penelitian ini menggunakan instrumen yaitu kuisioner yang telah diuji validitas dan reabilitasnya dengan hasil Cronbach's Alpha $=0,980$ dan telah memperoleh persetujuan etik dengan Ethical Exemption No.692/F/KEP/USM/II/2021. Setelah data terkumpul, maka dilakukan proses pengolahan data dengan metode pengecekan data yang terkumpul, pengkodeaan untuk mempermudah pengolahan, entry data dan melakukan tabulasi. Selanjutnya data dianalisis secara komputerisasi untuk menganalisis korelasi antara variabel perilaku orang tua dengan kejadian stunting.

\section{HASIL}

Setelah pengolahan data, maka diperoleh hasil penelitian sebagai berikut :

Tabel 1. Perilaku Orangtua Tentang Seribu Hari Pertama Kehidupan $(n=59)$

\begin{tabular}{cccc}
\hline No & Perilaku Orangtua & f & \% \\
\hline 1 & Baik & 29 & 49,2 \\
2 & Tidak Baik & 30 & 50,8 \\
\hline \multicolumn{2}{r}{ Jumlah } & 59 & 100,0 \\
\hline
\end{tabular}

Berdasarkan tabel 1, dapat terlihat bahwa perilaku orangtua tentang seribu hari pertama kehidupan di wilayah kerja Puskesmas Desa Lama mayoritas dengan perilaku tidak baik sebanyak 30orang $(50,8 \%)$ dan minoritas dengan perilaku orangtua baik sebanyak 29 orang $(49,2 \%)$.

Tabel 2. Kejadian Stunting $(\mathbf{n}=59)$

\begin{tabular}{clcc}
\hline No & Kejadian Stunting & f & \% \\
\hline 1 & Tidak Stunting & 35 & 59,3 \\
2 & Stunting & 24 & 40,7 \\
\hline \multicolumn{2}{r}{ Jumlah } & 59 & 100,0 \\
\hline
\end{tabular}

Berdasarkan tabel 2, dapat terlihat bahwa kejadian stunting di wilayah kerja Puskesmas Desa Lama mayoritas dengan tidak stunting sebanyak 35 orang (59,3\%)dan minoritas dengan stunting sebanyak 24 orang $(40,7 \%)$.

Tabel 3. Korelasi Perilaku Orangtua Tentang Seribu Hari Pertama Kehidupan Dengan Kejadian Stunting $(\mathrm{n}=59)$ 
Agnes Purba | Analisis Keterkaitan Perilaku Orangtua Tentang Seribu Hari Pertama Kehidupan Dengan Kejadian Stunting Di Wilayah Kerja Puskesmas Desa Lama

\begin{tabular}{|c|c|c|c|c|c|c|c|c|}
\hline \multirow[t]{2}{*}{ No } & \multirow[t]{2}{*}{$\begin{array}{l}\text { Perilaku } \\
\text { Orangtua }\end{array}$} & \multicolumn{2}{|c|}{$\begin{array}{c}\text { Tidak } \\
\text { Stunting }\end{array}$} & \multicolumn{2}{|c|}{ Stunting } & \multicolumn{2}{|c|}{ Total } & \multirow[t]{2}{*}{$p$-value } \\
\hline & & $\mathbf{n}$ & $\%$ & $\mathbf{n}$ & $\%$ & $\mathbf{N}$ & $\%$ & \\
\hline 1 & Baik & 25 & 86,6 & 4 & 13,8 & 29 & 100,0 & 0,000 \\
\hline 2 & Tidak Baik & 10 & 33,3 & 20 & 66,7 & 30 & 100,0 & \\
\hline
\end{tabular}

Berdasarkan Tabel 8 di atas dapat dilihat bahwa dari 29 orang dengan perilaku orangtua tentang seribu hari pertama kehidupan dengan kategori baik terdapat 25 orang $(86,6 \%)$ dengan tidak stunting dan mengalami kejadian stunting sebanyak 4 orang $(13,8 \%)$. Kemudian dari 30 orang dengan perilaku orangtua tentang seribu hari pertama kehidupan dengan kategori

\section{PEMBAHASAN}

Berdasarkan hasil hasil penelitian ini dijelaskan bahwa perilaku ibu tentang seribu hari pertama kehidupan masih sangat rendah $(50,8 \%)$. Kemudian dari 30 orang dengan perilaku orangtua tentang seribu hari pertama kehidupan dengan kategori tidak baik terdapat 10 orang $(33,3 \%)$ dengan tidak stunting dan mengalami kejadian stunting sebanyak 20 orang (66,7\%). Hasil uji chi squaremenunjukkan bahwa terdapat korelasi antara perilaku orangtua tentang seribu hari pertama kehidupan dengan kejadian stunting di wilayah kerja Puskesmas Desa Lama $(p=0,000)$.

Pengetahuan kognitif merupakan domain yang sangat penting dalam membentuk perilaku seseorang (Notoatmodjo, 2012).Hal ini terjadi di wilayah kerja Puskesmas Desa Lama dengan fenomena yang terjadi menunjukkan masih banyak ibu hamil yang tidak paham soal stunting dan tidak meyakini bahwa stunting bisa terjadi akibat pola makan yang salah, sehingga ia tidak melakukan pencegahan sejak awal. Sebagian ibu merasa bahwa kehamilan adalah kondisi biasa saja, jadi tidak memperbaiki pola makannya. Sebagian lain menganggap bahwa makan saat hamil diperuntukkan bagi dua orang. Akibatnya, hanya porsi nasi yang ditambah, agar tidak baik terdapat 10 orang $(33,3 \%)$ dengan tidak stunting dan mengalami kejadian stunting sebanyak 20 orang $(66,7 \%)$. Hasil uji chi square menunjukkan bahwa terdapat nilai $p$-value $=0,000<0,05$, artinya terdapat korelasi perilaku orangtua tentang seribu hari pertama kehidupan dengan kejadian stunting di wilayah kerja Puskesmas Desa Lama.

kenyang. Belum lagi mitos untuk menghindari daging merah, makanan laut dan kacang-kacangan, yang akhirnya membuat ibu hamil kekurangan protein. Saat melahirkan, masih banyak ibu yang tidak melakukan IMD (inisiasi menyusui dini). Hasil penelitian ini juga didukung oleh Sunarsih et.,al (2017) yang menunjukkan bahwa pengetahuan ibu hamil tentang 1000 HPK di Puskesmas Melati II Jogjakarta termasuk kategori kurang $(50 \%)$ sehingga menimbulkan perilaku yang tidak mendukung kesehatan janin selama dalam kandungan, dimana ibu tidak menganggap penting akan hal-hal yang dikonsumsinya.

Hasil penelitian ini juga menganalisi dari kuisioner yang diisi oleh responden menunjukkan bahwa perilaku ibu tentang seribu hari pertama kehidupan meliputi periode dalam kandungan (280 hari) yaitu mengkonsumsi makanan tinggi protein misalnya telur, daging, ikan, tempe/tahu dan susu, mengkonsumsi makanan karbohidrat yang cukup misalnya nasi merah, kentang, pisang dan kacangkacangan, mengkonsumsi makanan mengandung lemak sesuai dengan kebutuhan misalnya kuning telur, minyak samin, kacang, minyak zaitun, minyak kelapa dan daging sapi, mengonsumsi zat besi (fe) minimal 90 tablet selama kehamilan, mengkonsumsi makanan yang 
berkalsium sesuai kebutuhan misalnya bayam, kacang kedelai, jeruk, aplukat, ikan salmon, oatmel dan susu kedelai dan memeriksakan kehamilan secara rutin minimal 4 x selama kehamilan.

Perilaku yang tidak baik yang menonjol yaitu pada pada periode dalam kandungan (280 hari) adalah tidak mengonsumsi zat besi (fe) minimal 90 tablet selama kehamilan sebanyak 32 orang $(54,2 \%)$. Keadaan ini tentunya ibu saat hamil tidak mendapat zat besi yang cukup, sementara zat besi (fe) berperan sebagai sebuah komponen yang membentuk mioglobin, yakni protein yang mendistribusikan oksigen menuju otot, membentuk enzim, dan kolagen. Selain itu, zat besi juga berperan bagi ketahanan tubuh.Tablet zat besi (Fe) penting untuk ibu hamil karena memiliki beberapa fungsi yaitu menambah asupan nutrisi pada janin mencegah anemia defisiensi zat besi, mencegah pendarahan saat masa persalinan dan menurunkan risiko kematian pada ibu karena pendarahan pada saat persalinan.

Perilaku yang tidak baik yang menonjol pada pada periode $0-6$ bulan adalah tidak memberikan ASI eksklusif selama 6 bulanmencapai 32 orang $(54,2 \%)$. Perilaku orangtua tentang seribu hari pertama kehidupan golden periode juga dapat dilihat dari saat bayi lahir yaitu dengan melakukan Inisiasi Menyusu Dini (IMD) langsung setelah bayi lahir, dan inisiasi ini sangat mendukung keberhasilan pemberian ASI Eksklusif. Memberikan ASI secara Eksklusif mulai bayi usia 0 -6 bulan, dan semua kebutuhan gizinya sampai dengan usia 0-6 bulan sudah terpenuhi dengan sempurna hanya dengan ASI saja. Setelah usia 6 bulan sampai usia 2 tahun, meneruskan pemberian ASI dengan makanan tambahan pendamping ASI (MP ASI), menimbang bayi tiap bulan di posyandu untuk dipantau tumbuh kembangnyaa. memberikan kapsul vitamin A dan imunisasi lengkap sesuai jadwal serta mencuci tangan pakai sabun dengan air mengalir sebelum memberi ASI.
Perilaku ibu yang tidak baik tersebut turut berkontribusi dengan terjadi stunting di wilayah kerja Puskesmas Desa Lama. Hal ini sejalan dengan penelitian Ismy dan Wahyuni (2019) yang mengemukakan bahwa pengetahuan dan perilaku orangtua berkorelasi $(\mathrm{p}=0,000)$ dengan kejadian stunting pada anak di Kelurahan Mesjid Kecamatan Samarinda. Rahmayana dan Damayanti (2014) menjelaskan menurut teori Blum faktor penentu status kesehatan seseorang adalah lingkungan dan perilaku. Faktor determinan yang paling kuat mempengaruhi dan paling sulit untuk dirubah adalah perilaku.

\section{KESIMPULAN}

Kesimpulan dari hasil penelitian ini bahwa perilaku tentang seribu hari pertama kehidupan merupakan determinan paling kuat untuk mempengaruhi kejadian stunting pada anak di Wilayah Kerja Puskesmas Desa Lama, untuk itu kepada petugas kesehatan dan instansi pusat kesehatan masyarakat di wilayah ini dapat memberikan promosi kesehatan sehingga dapat memberikan pemahaman pada orang tua akan pentingnya periode seribu hari pertama kehidupan bagi pertumbuhan balita dan anak.

\section{DAFTAR PUSTAKA}

Agus Samsudrajat S, \& Jati, S. P. (2018). Kebijakan Penyelamatan 1000 Hari Pertama Kehidupan (1000 HPK) dan Penurunan Stunting di Kota Semarang. Jurnal Manajemen Kesehatan Indonesia, 6(1), 1-7. https://doi.org/https://doi.org/10.1471 0/jmki.6.1.2018.1-7View

IDN Supariasa, B Bakri, \& I Fajar. (2012). Penilaian status gizi edisi revisi. Jakarta : EGC.

Ismi, Nur Afifah dan Wahyuni, Marjan. (2019). Hubungan Perilaku Orangtua dengan Kejadian Stunting pada Balita di RT 08 Kelurahan Mesjid Kecamatan Samarinda Seberang. Borneo Student Research. 
Kemenkes RI. (2016). Infodatin Situasi Balita Pendek. Jakarta.

Khoirun Ni'mah, \& SR Nadhiroh. (2015). Faktor yang Berhubungan dengan Kejadian Stunting pada Balita. Media Gizi Indonesia., 10(1), 13-19. https://doi.org/http://dx.doi.org/10.20 473/mgi.v10i1.13-19

L Mubasyiroh, \& Z C Aya. (2018). Hubungan Perilaku Ibu Dalam Pemenuhan Gizi Pada Anak 1000 Hari Pertama Kehidupan/ Golden Period Dengan Status Gizi Balita Di Desa Sitanggal Kecamatan Larangan Kabupaten BrebesTahun 2018. Jurnal Ilmi Kesehatan Bhakti Husada, 09(01), 18-28. https://doi.org/10.34305/jikbh.v9i1.58

NHF Losong, \& M Adriani. (2017). Perbedaan Kadar Hemoglobin, Asupan Zat Besi, dan Zinc pada Balita Stunting dan Non Stunting. Amerta Nutrition, 1(2), 117-123. https://doi.org/http://dx.doi.org/10.20 473/amnt.v1i2.2017.117-123

Notoatmodjo S. (2012). Pendidikan dan perilaku kesehatan. Jakarta: Rineka Cipta.

Sunarsih, T., Dewi, D., \& ARS Putri. (2020). Hubungan Pengetahuan Ibu Hamil Tentang Program 1000 Hari Pertama Kehidupan Dengan Stimulasi Anak Dalam Kandungan. Media Kesehatan Masyarakat Indonesia, 19(1).

https://doi.org/https://doi.org/10.1471

0/mkmi.19.1.83-89 